\title{
Pendampingan Penulisan Artikel Ilmiah Layak Jurnal Nasional Ber-ISBN Berbasis Sitasi Online Bagi Tenaga Pendidik Se-Kabupaten Bondowoso
}

\author{
${ }^{1 *}$ Imron Arifin, ${ }^{2}$ Juharyanto, ${ }^{3}$ Sultoni, ${ }^{4}$ Bagus Rachmad Saputra, ${ }^{5}$ Maulana Amirul Adha, \\ ${ }^{6}$ Athalla Nauval Bhayangkara, ${ }^{7}$ Karine Rizkita, ${ }^{8}$ Putri Wulandari \\ Universitas Negeri Malang; Jalan Semarang 5 Malang \\ *Corresponding author: imron.arifin.fip@um.ac.id
}

\begin{abstract}
Abstrak
Tujuan pengabdian masyarakat melalui program pendampingan sitasi berbasis mendeley dalam penulisan artikel layak jurnal bereputasi bagi tenaga pendidik se Kabupaten Bondowoso ini adalah membekali pengetahuan dan keterampilan menyusun artikel kepada para tenaga pendidik se Kabupaten Bondowoso. Luaran dari kegiatan pendampingan tersebut antara lain: artikel layak jurnal berbasis sitasi otomatis dengan plug in mendeley dan artikel pengabdian.Strategi pelaksanaan kegiatan ini antara lain workshop, penugasan, pendampingan individual, fasilitasi pencarian jurnal untuk penerbitan artikel. Strategi pelaksanaan dilaksanakan secara terintegrasi dengan metode: ceramah, tanya jawab, diskusi, modelling, discovery, problem based learning, dan penugasan, serta advokasi.Hasil yang diperoleh adalah peserta memiliki kemampuan dan keterampilan dalam penyusunan artikel berbasis sitasi otomatis dengan plug in mendeley. Hal tersebut diketahui dari luaran berupa draf artikel berbasis sitasi otomatis dengan plug in mendeley yang disusun para guru yang dihasilkan dalam dua hari workshop.
\end{abstract}

Kata kunci-pendampingan, penulisan, karya tulis ilmiah, artikel berbasis sitasi otomatis.

\begin{abstract}
The aim of community service through Mendeley-based citation assistance programs in writing articles worthy of reputable journals for educators in Bondowoso Regency is to equip knowledge and skills in preparing articles for educators in Bondowoso Regency. The outputs of the mentoring activities include: proper articles based on automatic citation-based journals with plug-in delays and service articles. The strategy for carrying out these activities includes workshops, assignments, individual assistance, facilitation of journal search for article publishing. The implementation strategy is implemented in an integrated manner with methods: lecture, question and answer, discussion, modeling, discovery, problem based learning, and assignment, as well as advocacy. The results obtained are participants have the ability and skills in preparing automatic citation-based articles with plug-in mendeley. This is known from the output in the form of an automatic citation-based article with a plug-in mendey prepared by the teachers produced in two days of the workshop.
\end{abstract}

Keywords-assistance, writing, scientific papers, automatic citation-based articles

\section{PENDAHULUAN}

$\mathrm{U}$ ndang-Undang Sisdiknas No. 20 Tahun 2003, yang di breakdown ke dalam keseluruhan peraturan perundang-undangan yang menyertai, sepakat bahwa seluruh anak bangsa harus mendapatkan layanan pendidikan dan pengajaran yang berkualitas, tanpa tebang pilih. Mutu Sumber Daya Manusia Indonesia yang berkualitas, hanya dapat diraih melalui penyediaan dan penyelenggaraan pendidikan yang berkualitas. Kualitas dan kerja keras para tenaga pendidik menjadi ujung tombak penentu keberhasilan pendidikan dalam memaksimalkan kreativitas dan kompetensinya melalui beragam kegiatan, salah satunya adalah penelitian dan pengembangan dirinya secara kontinu dengan karya inovatif dan dinamis (Liljenberg, 2014; $\mathrm{Ng}, 2013$; Ramadhan, 2013; Yagnamurthy, 2013).

Guru sebagai tenaga profesional mempunyai fungsi, peran, dan kedudukan yang sangat penting dalam mencapai visi pendidikan 2025 yaitu menciptakan insan Indonesia cerdas dan kompetitif. Profesi guru harus dihargai dan dikembangkan sebagai profesi yang bermartabat sebagaimana diamanatkan dalam Undang-undang Nomor 14 Tahun 2005 tentang Guru dan Dosen (UGD) dan Peraturan 
Menteri Pendidikan Nasional Nomor 35 Tahun 2010 Tentang Petunjuk Teknis Pelaksanaan Jabatan Fungsional Guru dan Angka Kreditnya. Konsekuensinya, pengembangan Keprofesian berkelanjutan (PKB), yang berupa pengembangan kompetensi guru yang dilaksanakan sesuai dengan kebutuhan, bertahap, berkelanjutan untuk meningkatkan profesionalitasnya, dengan cakupan pengembangan diri, publikasi ilmiah dan karya inovatif, menjadi sebuah keharusan untuk ditindaklanjuti melalui berbagai wadah fasilitatif, salah satunya melalui wadah artikel berbasis sitasi otomatis dengan plug in mendeley (Brown dkk., 2016; Ng \& Szeto, 2016; Shannon \& Bylsma, 2003; Su, Gamage, \& Mininberg, 2003).

Urgensi penyediaan jurnal pendidikan, merupakan kebutuhan setiap warga negara yang peduli dengan pengembangan pendidikan, terutama para tenaga pendidik (Juharyanto, 2012). Sebagai wadah terhadap keseluruhan aspirasi dan ide kreatifinovatif, artikel berbasis sitasi otomatis dengan plug in mendeley tidak saja menjadi barometer utama terhadap capaian kinerja pemerintah di bidang pemberdayaan pendidikan melalui kegiatan penelitian, pengabdian, dan pengembangan para tenaga pendidikan, melainkan menjadi media strategis dalam sosialisasi keilmuan yang bertanggungjawab (accountable knowledge share) dan motivatif yang berujung pada lahirnya konsep keilmuan baru dan strategis bagi pendidikan di tingkat satuan pendidikan.

Ciri-ciri artikel ilmiah adalah: (1) logis, yakni segala informasi yang disajikan memiliki argumentasi yang dapat diterima dengan akal sehat, (2) sistematis, yakni segala yang dikemukakan disusun berdasarkan urutan yang berjenjang dan berkesinambungan, (3) objektif, yakni segala informasi yang dikemukakan itu menurut apa adanya dan tidak bersifat fiktif, (4) tuntas dan menyeluruh, yakni segi-segi masalah yang dikemukakan ditelaah secara lengkap, (5) saksama, yakni berusaha menghindarkan diri dari berbagai kesalahan, (6) jelas, yakni segala keterangan yang dikemukakan dapat mengungkapkan maksud secara jernih, (7) kebenarannya dapat teruji, (8) terbuka, maksudnya sesuatu yang dikemukakan itu dapat berubah seandainya muncul pendapat baru, (9) berlaku umum, yakni kesimpulannya berlaku bagi semua populasinya, dan (10) penyajiannya memperhatikan santun bahasa dan tata tulis yang sudah baku (Ekosusilo \& Triyanto, 1995).

Di samping itu, Soehardjono (2006) berpendapat bahwa laporan penelitian harus memenuhi kriteria -APIK, yakni asli, penelitian harus merupakan karya asli penyusunnya, bukan merupakan plagiat, jiplakan, atau disusun dengan niat dan prosedur yang tidak jujur. Syarat utama karya ilmiah adalah kejujuran.
Ilmiah, penelitian harus berbentuk, berisi, dan dilakukan sesuai dengan kaidah-kaidah kebenaran ilmiah. Penelitian harus benar, baik teorinya, faktanya maupun analisis yang digunakannya. Konsisten, penelitian harus disusun sesuai dengan kemampuan penyusunnya. Bila penulisnya seorang guru, maka penelitian haruslah berada pada bidang keilmuan yang sesuai dengan kemampuan guru tersebut.

Artikel ilmiah berbasis sitasi otomatis dengan plug in mendeley ini juga menjadi sarana fasilitatif untuk membantu kelancaran pengembangan profesi dan jenjang prestasi para tenaga pendidik serta dalam rangka meningkatkan prestasi belajar peserta didik (Berkovich \& Eyal, 2019; Johnson et al., 2012; Ladyshewsky \& Flavell, 2012). Menurut Soehardjono (2006) prestasi kerja guru tersebut, sesuai dengan tupoksinya, berada dalam bidang kegiatannya: (1) pendidikan, (2) proses pembelajaran, (3) pengembangan profesi dan (4) penunjang proses pembelajaran.

Bahan ajar berupa artikel berbasis sitasi otomatis dengan plug in mendeley merupakan salah satu sumber belajar yang efektif bagi terciptanya proses belajar yang mandiri, terutama di jenjang pendidikan sekolah menengah kejuruan. Dalam hal ini, keberadaan SD - SMP dengan program pendidikan yang banyak mengedepankan aspek praktis melalui kerja sama dengan DUDI, di mana melalui program Pendidikan Sistem Ganda (PSG), tatap muka pembelajaran tidak lagi berlangsung di dalam ruang kelas. Keadaan ini menyebabkan tidak efektivitasnya pembelajaran, sehingga target kurikuler sulit sekali dapat diraih.

Proses pembelajaran Sekolah Menengah Kejuruan (SD - SMP) terdiri dari proses pembelajaran tatap muka dan Pendidikan Sistem Ganda (PSG) atau praktik kerja lapangan (PKL). Proses pembelajaran tersebut dilaksanakan sesuai dengan tujuan SD - SMP, yaitu; (1) mempersiapkan siswa untuk melanjutkan ke jenjang pendidikan yang lebih tinggi dan/atau meluaskan pendidikan dasar, (2) meningkatkan kemampuan siswa sebagai anggota masyarakat dalam mengadakan hubungan timbal balik dengan lingkungan sosial budaya dan alam sekitarnya, (3) meningkatkan kemampuan siswa untuk dapat mengembangkan diri sejalan dengan perkembangan ilmu pengetahuan, teknologi dan kesenian, dan (4) Menyiapkan siswa untuk lapangan kerja dan mengembangkan sikap profesional.

Menurut Majid (2006) artikel berbasis sitasi otomatis dengan plug in mendeley adalah buku yang ditulis dengan tujuan agar peserta didik dapat belajar secara mandiri tanpa atau dengan bimbingan guru, sehingga artikel berbasis sitasi otomatis dengan plug in mendeley berisi paling tidak tentang segala 
komponen dasar bahan ajar yang telah disebutkan sebelumnya. Sebuah artikel berbasis sitasi otomatis dengan plug in mendeley akan bermakna kalau peserta didik dapat dengan mudah menggunakannya. Pembelajaran dengan artikel berbasis sitasi otomatis dengan plug in mendeley memungkinkan seorang peserta didik yang memiliki kecepatan tinggi dalam belajar akan cepat menyelesaikan satu atau lebih kompetensi dasar dibandingkan dengan peserta didik lainnya. Dengan demikian artikel berbasis sitasi otomatis dengan plug in mendeley harus menggambarkan kompetensi dasar yang akan dicapai oleh peserta didik, disajikan dengan menggunakan bahasa yang baik, menarik, dilengkapi dengan ilustrasi.

Salah satu permasalahan umum dalam penyusunan karya ilmiah adalah masalah sitasi atau pengutipan. Tidak sedikit karya ilmiah yang mengalami inkonsistensi pengutipan. Disamping inkonsistensi tersebut, rujukan yang digunakan cenderung sudah usang. Sejalan dengan perkembangan informasi dan teknologi di bidang penulisan karya ilmiah, terdapat beberapa aplikasi sitasi yang dapat dilakukan secara online maupun offline, salah satunya adalah aplikasi mendeley dekstop. Program tersebut memberi kemudahan dalam beberapa hal, antara lain: 1) memudahkan pengutipan sesuai standar penerbit yang diinginkan; 2) memfasilitasi proses up dating data atau sumber rujukan, baik dalam bentuk buku maupun jurnal serta karya ilmiah lainnya. Dengan mendeley dekstop yang hanya membutuhkan ruang hard-disk tidak lebih dari 17 MB dan serta spesifikasi laptop atau komputer yang sederhana, keberadaannya akan membantu peneliti atau penulis dalam melakukan sitasi atau pengutipan dengan sangat cepat dan mudah.

Menurut Data Pokok Pendidikan (DAPODIK), Kantor Dinas Pendidikan Kota Malang tahun 2019, Dinas Pendidikan Kota Malang, melalui Kepala Sub Bagian Program dan Perencanaan, membina sebanyak 3.934 tenaga pendidik dengan status PNS sebanyak 252 orang dan non PNS sebanyak 3.682 orang pendidik. Hasil penelusuran awal yang kami lakukan dan koordinasikan dengan Kepala Sub Bagian Program dan Perencanaan Dinas Pendidikan dan Kebudayaan Wilayah Kabupaten Bondowoso terhadap potensi kuantitatif tenaga pendidik tersebut, Dinas Pendidikan Kota Malang tidak akan kekurangan artikel/makalah hasil penelitian para Tenaga Pendidik hingga dalam kurun waktu $3-6$ tahun ke depan (2022). Hal tersebut bermakna bahwa akan terjadi proses sharing keberhasilan dan pengalaman pembelajaran (best practices) antar sesama tenaga pendidik melalui jurnal Pendidikan yang diterbitkan sebanyak tiga kali setiap tahunnya yang akan memberikan kontribusi terhadap upaya peningkatan mutu pendidikan Wilayah Kabupaten Bondowoso secara signifikan.

Tetapi dalam kenyataannya, perjalanan jurnaljurnal yang dikelola oleh instansi pendidikan lainnya selama berhadapan dengan kendala kurangnya makalah/artikel di hampir setiap waktu penerbitannya. Penyebab utamanya adalah sangat kurangnya tenaga pendidik $(<5 \%)$ yang memiliki kemampuan untuk menulis artikel layak jurnal, di samping juga masih belum tersedianya jurnal pendidikan yang dapat memfasilitasi karya-karya berupa artikel para pendidik, khususnya berbasis penelitian tindakan kelas maupun sekolah. Dengan demikian, kegiatan pendampingan penulisan artikel menjadi sangat urgen dilakukan guna membantu membekali pengetahuan dan keterampilan mereka, sekaligus memfasilitasi kelancaran mereka dalam melakukan peningkatan keprofesionalan berkelanjutan (PKB) mereka sendiri. Tentu juga perlu tim yang kompeten untuk mengelola seluruh artikel para pendidik, untuk diterbitkan dalam suatu jurnal yang layak dan memadai serta berkekuatan hukum yang jelas dan tetap, yakni berISSN. Atas dasar permasalahan awal tersebut, perlu juga disusun tim pengelola jurnal yang kondusif bagi keberlangsungan jurnal yang akan diterbitkan terutama menyusun dan melaksanakan berbagai macam strategi dan pendekatan (vertikal/ horizontal) baik di internal Kantor Dinas Pendidikan dan Kebudayaan (antar Kepala Seksi) maupun dengan pihak eksternal (Satuan Pendidikan, Tokoh Masyarakat dan Pemerhati Pendidikan, Perguruan Tinggi, DUDI, dll.) untuk mendorong dan memotivasi mereka agar menulis makalah/artikel layak Jurnal. Masalah-masalah lainnya seperti, kurangnya sosialisasi tentang esensi jurnal, khususnya bagi pengembangan Keprofesian Berkelanjutan yang wajib diikuti oleh para pendidikan, khususnya yang berstatus sebagai Aparatur Sipil Negara (ASN).

Atas dasar deskripsi tersebut diketahui bahwa para tenaga pendidik sangat perlu didampingi dalam penyusunan artikel layak jurnal, terutama dalam hal melakukan sitasi/pengutipan otomatis, serta perlu diterbitkan jurnal, dan perlu motivasi berprestasi secara terus menerus melalui penulisan artikel berbasis PTK/PTS. Disamping itu, pendampingan berupa pemberian informasi dan motivasi yang tepat tentang hal-hal berkaitan dengan pentingnya publikasi karya ilmiah berupa artikel layak jurnal dan substansi regulasi tentang PKB yang sebenarnya, perlu dilakukan dan diwadahi. 


\section{METODE}

Dalam upaya memaksimalkan keberhasilan pelaksanaan Pendampingan sitasi berbasis mendeley dalam penulisan artikel berbasis sitasi otomatis dengan plug in mendeley untuk guru SD - SMP Kabupaten Bondowoso. ini, metode yang digunakan antara lain: Ceramah, Diskusi, Tanya Jawab, Modelling, Discovery, Problem Based Learning, dan Penugasan. Metode-metode tersebut terintegrasi ke dalam strategi Workshop.

Disamping hal tersebut di atas, guna mendukung kelancaran, keterlaksanaan, dan keberhasilan Workshop ini, maka digunakan pula beragam pendekatan budaya sesuai dengan karakteristik peserta secara individual, mengedepan-kan aspek konstruktivistik, dan mengutamakan jalinan keakraban ala santri, dengan tetap menitikberatkan pada fokus kegiatan yang dilaksanakan.

\section{HASIL DAN PEMBAHASAN}

Pendekatan melalui beragam metode, strategi dan teknik yang disajikan dan dicontohkan selama kegiatan Workshop, hasil substantif kegiatannya dapat dideskripsikan dapat dibagi ke dalam dua bentuk hasil kegiatan, yaitu hasil kegiatan langsung dan hasil kegiatan tidak langsung. Hasil kegiatan langsungnya antara lain: 1) terjadi peningkatan penguasaan materi tentang pengetahuan dan keterampilan penyusunan artikel berbasis sitasi otomatis dengan plug in mendeley pada guru dan kepala SD - SMP se Kabupaten Bondowoso Jawa Timur Tahun 2019 yang sangat signifikan, yakni mencapai 87 persen peserta meraih nilai rata-rata post-tes sebesar $74 ; 2$ ) dari refleksi yang dilakukan penyaji, peserta memperoleh informasi yang baik tentang Pengetahuan dan keterampilan penyusunan artikel berbasis sitasi otomatis dengan plug in Mendeley pada guru dan kepalaSD - SMP se Kabupaten Bondowoso Jawa Timur Tahun 2019; 3) peserta memiliki kemampuan dalam mengidentifikasi dan menentukan karakteristik artikel berbasis sitasi otomatis dengan plug in mendeley yang baik yang memungkinkan terjadinya perubahan ke arah lembaga pendidikan berprestasi atau unggulan dengan cukup baik sesuai dengan ketentuan yang penyaji sampaikan dan pemahaman atas sajian materi tersebut; 4) peserta menghasilkan kriteria kunci dalam mengidentifikasi dan menentukan karakteristik artikel berbasis sitasi otomatis dengan plug in mendeley yang baik.

Hasil kegiatan tidak langsungnya antara lain: 1) secara umum pelaksanaan Workshop Pengetahuan dan keterampilan penyusunan artikel berbasis sitasi otomatis dengan plug in mendeley pada guru dan kepala SD - SMP se Kabupaten Bondowoso Jawa Timur Tahun 2019 tersebut berdampak positif bagi terbangun dan meningkatnya motivasi peserta dalam selama maupun pasca kegiatan Workshop; 2) hampir $100 \%$ peserta merasa puas dengan sajian narasumber selama Workshop, hal ini tampak dalam hasil evaluasi narasumber yang meraih nilai rata-rata 98, dengan aspek penilaian: penguasaan materi, penguasaan peserta dan kelas, pemilihan dan pelaksanaan metode dan strategi, dan kejelasan (artikulasi dan informasi) yang disampaikan, serta kedekatan dengan peserta (rapport), dan lain-lain; 3) semua peserta masih berkeinginan untuk menindaklanjuti hasil Workshop, terutama tampak pada semangat untuk menyelenggarakan Workshop lanjutan yang berkaitan dengan Pengetahuan dan keterampilan penyusunan artikel berbasis sitasi otomatis dengan plug in Mendeley pada guru dan kepala SD - SMP se Kabupaten Bondowoso Jawa Timur Tahun 2019.

Pembinaan, apapun bentuknya merupakan kebutuhan bagi siapapun, termasuk guru SD - SMP. Pembinaan terhadap para guru dan seluruh unsur sekolah dapat memberikan dampak positif terhadap terjadinya perubahan mutu sekolah (Bencze, 2008; Reddy, Kurian, \& Ardakanian, 2015). Hasil suatu pembinaan dapat meningkatkan motivasi. Semakin tinggi motivasi yang diraih, akan semakin tinggi pula prestasi yang akan ditunjukkan (Gilbert et al., n.d.; Shun-wing Ng, 2014; Walker, 2011). Salah satu hal penting yang dapat ditunjukkan para guru dengan motivasi tinggi adalah tingginya kinerja guru dalam menyusun bahan ajar, salah satunya artikel berbasis sitasi otomatis dengan plug in mendeley. Bagaimanapun SD - SMP memerlukan artikel berbasis sitasi otomatis dengan plug in mendeley guna mengurangi keterbatasan waktu pembelajaran ( $\mathrm{Li}$, 2013; Phelan, 2015; Procedure, 2017).

Keberhasilan workshop dapat pula didukung oleh strategi dan teknik yang diterapkan oleh instruktur. Bangunan rapport yang sengaja diusahakan oleh para instruktur sangat menentukan kualitas keterlibatan peserta dalam kegiatan tersebut (Bencze, 2008; King, Goodson, \& Rohani, 1998; Mayaru, 2015). Semakin tinggi usaha membangun rapport yang dilakukan, akan menentukan tingginya interaksi dan keterlibatan peserta, dan berarti akan semakin tinggi kualitas keberhasilan dari pembelajaran atau training yang dilakukan.

\section{SIMPULAN}

Berdasarkan hasil pelaksanaan kegiatan workshop tentang Artikel berbasis sitasi otomatis dengan plug in mendeley yang baik pada guru dan kepala SD - SMP se Kabupaten Bondowoso Jawa 
Timur tahun 2019, dapat disimpulkan: a) sekolah/Madrasah di guru dan kepala SD - SMP se Kabupaten Bondowoso Jawa Timur merespons positif terhadap penyelenggaraan Workshop, khususnya tentang artikel berbasis sitasi otomatis dengan plug in mendeley yang baik dalam rangka meningkatkan dan mengembangkan kualitas sumber daya menuju keunggulan sekolah/madrasah; b) manfaat besar yang dirasakan dan dialami selama Workshop, menstimulasi geliat besar dalam upaya peningkatan prestasi dan keunggulan sekolah/madrasah. 3) sekolah/madrasah berkeinginan untuk melanjutkan dan mengembangkan Workshop (tidak hanya tentang Pengetahuan dan keterampilan penyusunan artikel berbasis sitasi otomatis dengan plug in mendeley) di masa-masa yang akan datang.

\section{DAFTAR RUJUKAN}

Bencze, J. L. (2008). Constructivist science and technology education (Vol. 2016). Retrieved from

http://webspace.oise.utoronto.ca/ benczela/Con structivist SandTed.html

Berkovich, I., \& Eyal, O. (2017). The mediating role of principals ' transformational leadership behaviors in promoting teachers ' emotional wellness at work: A study in Israeli primary schools, 45(2), 316-335. https://doi.org/10.1177/1741143215617947

Brown, C., Militello, M., Brown, C., Elementary, B. J. M., \& Carolina, N. (2016). Principal 's perceptions of effective professional development in schools. Journal of Educational Administration, 54(6), 703-726. https://doi.org/10.1108/JEA-09-2014-0109

Gilbert, I., Motivation, E., Holleran, G., Gilbert, I., Thinking, I., Motivation, E., ... Google, G. (n.d.). A Teacher' $s$ Companion to Essential Motivation in the Classroom.

Johnson, B., Down, B., Le Cornu, R., Peters, J., Sullivant, A., Pearce, J., \& Hunter, J. (2012). Early Career Teachers: Stories of Resilience. https://doi.org/10.1007/978-981-287-173-2

Juharyanto. (2012). Implementasi Kompetensi Kepala Sekolah Sebagai Agen Perubahan pada Sekolah Berprestasi: Studi Multi Kasus Pada Tiga SD/MI Berprestasi Di Kabupaten Bondowoso, Kabupaten Jember dan Kabupaten Situbondo. $\mathrm{Ph} . \mathrm{D}$ Thesis Universitas Negeri Malang.

King, F. J., Goodson, L., \& Rohani, F. (1998). Higher Order Thinking Skills. Publication of the Educational Services Program, Now Known as the Center for Advancement of Learning and Assessment. Obtido de: Www.Cala.Fsu.Edu, 1-
176.

Retrieved

from

http://www.cala.fsu.edu/files/higher_order_thin king_skills.pdf

Ladyshewsky, R. K., \& Flavell, H. (2012). Transfer of Training in an Academic Leadership Development Program for Program Coordinators. Educational Management Administration \& Leadership, 40(1), 127-147. https://doi.org/10.1177/1741143211420615

Li, E. H.-F. L. \& C. (Ed.). (2013). Curriculum Innovations in Changing Societies. Rotterdam: Sense Publishers. https://doi.org/10.1007/97894-6209-359-1

Liljenberg, M. (2014). Distributing leadership to establish developing and learning school organisations in the Swedish context. Educational Management Administration \& Leadership, $\quad 43(1), \quad$ 152-170. https://doi.org/10.1177/1741143213513187

Makene Obadia Mayaru. (2015). the Challenges Facing the Public Primary School. Open University of Tanzania.

Ng, S., \& Szeto, S. E. (2016). Preparing school leaders : The professional development needs of newly appointed principals, 44(4), 540-557. https://doi.org/10.1177/1741143214564766

Ng, S. W. (2013). Equipping Aspiring Principals for the Principalship in Hong Kong. Educational Management Administration \& Leadership , 4l(3), 272-288. https://doi.org/10.1177/1741143212474807

Phelan, A. M. (2015). Curriculum Theorizing and Teacher Education. Teacher Education Systems in Africa in the Digital Era. https://doi.org/10.4324/9780203387078

Ramadhan, P. A. (2013). Teacher and health worker absence in Indonesia. Asian Education and Development Studies, 2(2), 149-161. https://doi.org/10.1108/20463161311321420

Procedure, W. H. S. (2017). Induction and Training Form, (June), 335.

Reddy, V. R., Kurian, M., \& Ardakanian, R. (2015). Life-cycle Cost Approach for Management of Environmental Resources. https://doi.org/10.1007/978-3-319-06287-7

Shannon, G. S., \& Bylsma, P. (2003). Nine Characteristics of High Performing Schools. Olympia, WA: OSPI, 1-39. https://doi.org/10.1136/pgmj.2008.075523

Shun-wing Ng, T. K. C. (2014). Continuing professional development for middle leaders in primary schools in Hong Kong. Journal of Educational Administration, 52(6), 869-886. https://doi.org/10.1108/JEA-07-2013-0077 
Su, Z., Gamage, D., \& Mininberg, E. (2003). Professional preparation and development of school leaders in Australia and the USA. International Education Journal, 4(1), 42-59.

Walker, C. (2011). Managing student motivation through teaching performance.

Yagnamurthy, S. (2013). How schools function in the districts affected by left-wing extremism in India. Asian Education and Development Studies, 2(3), 263-274. https://doi.org/10.1108/AEDS-102012-0041. 